\title{
COMMENT
}

\section{LABOR'S COERCIVE ACTIVITIES UNDER THE SHERMAN ACT-THE APEX CASE}

Chardes O. Gregory*

$\mathrm{I}$ N Leader v. Apex Hosiery Co. ${ }^{\mathrm{x}}$ the Third Circuit Court of Appeals recently attempted to restate the position of the Supreme Court on the application of the Sherman Act to the coercive activities of organized labor. The result is, however, not very illuminating. But this is not altogether the fault of the Third Circuit Court of Appeals. The Supreme Court itself has obscured its views in language so vague and fictional that one wonders whether it can be said ever to have taken any position except as it has disposed of particular cases. Nevertheless, I believe some light can be thrown on a few of the leading cases-enough, at least, to show that although the $A$ pex case will probably be affirmed, the trial court's judgment in favor of the plaintiff might easily have been founded on evidence which might have prevented its reversal.

Whether or not Congress intended the Sherman Act to cover the coercive activities of labor unions or meant what it seemed to say in Section 6 of the Clayton Act is now hardly worth discussion. These issues have been exhaustively treated elsewhere. It is sufficient here to note that Congress in the Sherman Act declared illegal "every .... combination .... in restraint of trade or commerce among the several States. ..." Since the phrase "restraint of trade" was more or less a term of art at common law" signifying the effects of monopolistic practices of dealers in goods, perhaps I should emphasize in passing its unusual use to describe the prevention of goods from entering into commerce.

When the Supreme Court decided the Danbury Hatters ${ }^{4}$ case in 1908 , it embarked upon a precarious venture. For all successful coercive labor

* Associate Professor of Law, University of Chicago Law School.

I Leader v. Apex Hosiery Co., C.C.H. Lab. Law Serv. If 18482 (C.C.A. 3 d I939). The District Court's charge to the jury and the judgment for triple damages appear in C.C.H. Lab. Law Serv. II 18336 (D.C. Pa. 1939).

2 Petition for cert. filed January 22, 1940 .

3 See opinion of Taft, J., ad lib. in United States v. Addyston Pipe \& Steel Co., 85 Fed. 27 I (C.C.A. 6 th $r 898$ ).

1 Loewe v. Lawlor, 208 U.S. 274 (rgo8). 
activities, at least in plants engaged in the production of goods to be sent into other states, involve restraints on such shipments. And if such restraints are caused by the coercive activities of labor combinations, they would all seem to fall within the prohibitions of the act. If so, Congress had in one brief statute wiped out the privileges of coercive bargaining for which organized labor had fought so long and so bitterly, at least in those industries engaged in production for out of state markets.

But the Supreme Court had no intention of going so far. By I908, practically all of our courts, federal as well as state, had accepted strikes for higher wages and shorter hours. Even if such strikes by causing shutdowns did result in the prevention of shipments to other states, it would be neither practical nor politic, let alone just, to condemn them as violations of the Sherman Act. If the court wished to use this statute as a means of controlling labor union activities, it would have to hit upon some device other than the mere restraint of commerce involved. This standard was not sufficiently selective.

Perhaps the most obvious recourse was to condemn as illegal under the act those coercive union activities which were illegal aside from its provisions. Indeed, the Third Circuit Court of Appeals, as formerly constituted, in disposing of the Apex Company's request for injunctive relief, 5 indicated that lawful economic union coercion cannot be a violation of the Sherman Act. Even if this were true, it would, of course, be a long way from implying that all illegal conduct which involves a restraint of commerce is contrary to the terms of the act. At any rate, the Supreme Court in the first Coronado ${ }^{6}$ case refused to treat as a violation of the act the restraint caused by the highly illegal conduct of the strikers. Instead of this possible view, the Court announced that only "direct" restraints were condemned under the statute; and it added that "direct" restraints were only those actually intended or necessarily involved in the particular coercive activity practiced.

This principle, if it may be called one, is neither easy to understand nor simple to apply. As a part of the common law of torts, it had long since become traditional to infer from deliberate conduct an intent to do whatever followed from such conduct. Thus, if a successful strike for higher wages forced a manufacturer to cease production and prevented the shipment of goods to out of state customers, the strikers, by intending to force a shutdown, also intended the incidental stoppage of interstate ship-

5 Apex Hosiery Co. v. Leader, go F. (2d) I55 (C.C.A. 3 d I937), noted in 5 Univ. Chi. L. Rev. $x_{49}$ (r937), and rev'd as moot 302 U.S. 656 (r937).

${ }^{6}$ United Mine Workers of America v. Coronado Coal Co., 259 U.S. 344 (1922). 
ments. But the Supreme Court refused to extend this traditional reasoning to labor dispute cases arising under the Sherman Act. It said that the admitted restraint in such cases was not the coercive pressure which the strikers had set out to exercise. They were not trying to embarrass the manufacturer by preventing the shipment of his goods. They were trying to embarrass him by withholding their services in order to compel him to lose money through discontinuance of productive operations. Any "restraint" thereby placed on his out of state trade was incidental to the immediate objective of forcing him to comply with their demands by disabling him from continued production.

As a statement, this should be fairly simple to comprehend. But it is far from easy to understand why the Court took this position. Although the fact that strikes over wages and hours were not regarded as "bad" strikes had something to do with it, this may not be the whole answer. For I am sure that the Court would have treated such strikes as violations of the Sherman Act had it been proved that the strikers actually intended and tried to coerce the employer by preventing or interfering with his interstate shipments. But this would be very hard to prove in strikes over wages and hours, chiefly because the strikers find that stopping operations is sufficiently coercive.

But the Court's position may have been evolved much more subtly. A perusal of the last half century's output of court decisions on labor disputes would indicate a widespread determination to check coercive activities designed to promote the spread of union organization. The courts, with some exceptions, disliked the closed union shop movement and more or less consistently declared it to be an illegal objective of union coercive activities. The federal judiciary, including the Supreme Court, obviously shared this view. When it came to administering the Sherman Act in labor dispute cases, the Supreme Court may have finally concluded to employ its sanctions only against labor activities aimed at organization and the increase of union power. To this end, I believe it conceived what we might call the "intent formula," stating and applying it in such a way that it would be very hard, if not impossible, for the Department of Justice and for private litigants to prove a violation of the Sherman Act in cases of strikes over wages and hours, but relatively simple to prove a violation in cases of certain undesirable union practices committed for any purpose or in cases of any coercive activities aimed at the closed union shop.

This assertion may seem far-fetched to some readers. I say this because some of my friends with whom I have discussed this notion have felt that I attribute almost Machiavellian subtlety to a court of rather forthright and 
practical-minded judges. But I fail to see anything fantastic in supposing that the Court would hit upon a very technical formula to use as a guide for discriminating between permitted and illegal restraints, particularly in connection with anything as highly charged with politics as the organized labor movement. It has achieved distinctions infinitely more fantastic in cases involving taxation, conflict of laws and the Constitution.

But to come back to the "intent formula," the first hint of it appeared in the Coronado case. There the strikers by violence and terrorism had shut down a mine from which several thousand tons of coal a week were normally shipped to out of state markets. The court refused to treat this "incidental" restraint as a violation of the Sherman Act because it had not been shown that the strikers had intended it. But Chief Justice Taft certainly took the opportunity offered in the first Coronado case to lay down the basis for what was to become the ratio decidendi in the second Coronado case. ${ }^{7}$ His opinion shows that he appreciated the union policy of introducing the closed shop into all units of an industry in order to eliminate in national markets the competition of cheaper nonunion produced goods with the more costly union produced commodities. He realized that pursuit of this policy was essential to the business protection not only of unionized shops and mines but also of union laborers whose continued prosperity was dependent upon the economic welfare of their employers. All of this and its connection with coercive union activities for the closed shop he made clear in the first Coronado case. Nevertheless, he made it clear that general knowledge of this policy, as it had been frequently articulated by the national coal miners' union, was not the sort of evidence from which the federal courts in proceedings under the Sherman Act could infer that any particular closed shop strike called by a local union was designed to achieve unionization of that mine in order to keep its otherwise nonunion mined coal out of interstate markets. This inference, he said, must be supported by "circumstances or direct evidence" clearly showing that the local strike in question was actually and consciously intended to keep nonunion mined coal out of interstate markets in order to obviate cheaper competition with more expensive union mined coal. For all he could tell from the evidence, the strike in the Coronado case was intended merely to achieve added bargaining power and increased wages thereby.

Chief Justice Taft recognized an exception to these remarks. He said that the Danbury Hatters case was "very different." There the AFL had sought to bring pressure on Loewe in Connecticut by instituting a nation-

${ }^{7}$ Coronado Coal Co. v. United Mine Workers of America, 268 U.S. 295 (I925). 
wide secondary boycott against Loewe's hats. All federation members were dragooned into boycotting Loewe's hats and the stores where they were sold, with the specific object of discouraging retail hat shops-throughout the country from continuing to stock and order the plaintiff's hats. The federated union sought to bring pressure against the plaintiff by deliberately striking at and trying to annihilate his out of state market. As the Chief Justice observed: "The direct object of attack was interstate commerce." Presumably the Duplex ${ }^{8}$ and Bedford Cut Stone $e^{9}$ cases fell within the same category as the Danbury Hatters case. And Chief Justice 'Taft went on to show that the Lumber Dealers' Association ${ }^{\text {ro }}$ case was more like the Danbury Hatters case than it was like the first Coronado case. There a retail dealer's association blacklisted a wholesale lumber dealer because he sold lumber directly to consumers, thus infringing upon what the association members regarded as their proper custom. Inasmuch as the association's coercion was practiced upon the wholesaler by striking at his shipments to association members and was directed at curtailing his shipments to consumers, the Court regarded its conduct as an illegal restraint. As Chief Justice Taft remarked of this case: "It was the commerce itself which was the object of the conspiracy."

Parenthetically, I cannot help observing that the Lumber Dealers' Association case meant that purchasers of goods cannot band together and collectively refrain from dealing with another as labor unionists may do in ordinary strikes which are not intentionally aimed at interstate shipments. The explanation for this curious result no doubt lies in the nature of the dealings refrained from in the two types of cases, although this is a pretty thin distinction. In the Lumber Dealers' Association case, the only way in which the members could bring pressure (the only way in which they could cease dealing) involved the discontinuance of interstate shipments of lumber. But in an ordinary strike the method used to bring pressure is the collective withdrawal of services, a device which in the nature of things would hardly be described as coercion exercized through destruction of interstate shipments.

In the first Coronado case, Mr. Justice Taft gave a broad hint to counsel for the plaintiff. It was substantially the following: If you can find evidence indicating that the strikers actually intended to unionize the Coronado mine or, failing that, to shut it down, in order not only to improve their local bargaining strength and working conditions but also to

8 Duplex Printing Press Co. v. Deering, 254 U.S. 443 (I92I).

9 Bedford Cut Stone Co. v. Journeymen Stone Cutters' Ass'n, 274 U.S. 37 (I927).

10 Eastern States Retail Lumber Dealers' Ass'n v. United States, 234 U.S. 600 (Igr4). 
protect already unionized mine operators and their employees by keeping nonunion mined coal out of interstate markets, then the federal courts will regard the local strike as an illegal restraint under the Sherman Act. All counsel had to do was find someone who could testify as to the purposes of the strike. Apparently this was not hard to do; and, as is almost invariably true of strikes for the closed union shop, it transpired that one of its objectives was the elimination in national markets of the competition of nonunion produced goods with union produced commodities.

An observation of Chief Justice Taft's in the second Coronadors case is worth noting. He remarked:

The mere reduction in the supply of an article to be shipped in interstate commerce by the illegal or tortious prevention of its manufacture or production is ordinarily an indirect and remote obstruction to commerce. But when the intent of those unlawfully preventing the manufacture or production is shown to be to restrain or control the supply entering and moving in interstate commerce, or the price of it in interstate markets, their action is a direct violation of the Anti-Trust Act.

Whether or not I am correct in supposing that the Supreme Court deliberately evolved a rule enabling "good" strikes in spite of obvious incidental restraints through shutdowns but condemning organizational strikes is certainly conjectural. But I have no doubt that this is the position at which the Court arrived. Inasmuch as the main plank in the union economic program is the protection of unionized industries and the union employees therein from the undermining influence of the competition from cheaper nonunion made products, I believe that all organizational coercive union activities aimed at the closed shop, single or universal (throughout a particular industry), are intentionally directed at eliminating such competition. Naturally, such activities have other objections as well. But I think the Supreme Court evolved a means for permitting under the Sherman Act all coercive labor activities designed to achieve immediate ends such as better wages or shorter hours and for condemning thereunder all such activities aimed at the spread of union power through the closed shop in industries serving national markets. The key to this position of the Court's is the industry of counsel in securing evidence indicating the actual intent on the part of the defendant unionists to achieve this purpose, a task which should not be difficult in all organizational coercive union activities and which is practically impossible in cases of strikes for immediate objectives aside from the single or universal closed shop.

At this point some might observe that the strike in the Leatherworkers's

Ir Coronado Coal Co. v. United Mine Workers of America, 268 U.S. 295 (I925).

I2 United Leather Workers Int'l Union v. Herkert \& Meisel Trunk Co., 265 U.S. 457 (x924). 
case was for a closed shop; yet the restraint of continued shipments therein because of enforced cessation from manufacture was not regarded by a majority of the Supreme Court as illegal under the Sherman Act. Indeed, it appeared from the case that the strikers knew that such a restraint would very likely occur and they "hoped" that it would as an added compulsion on the employer to concede the union demands. But nowhere in the record did it appear that counsel for the plaintiff had secured evidence indicating that the strikers intended to achieve this result or to eliminate the competition of nonunion made with union made leather goods in interstate commerce.

Before I go any further, perhaps I should mention in passing one other type of restraint which courts have occasionally recognized in order to condemn under the Sherman Act certain coercive activities of labor unions. This is the interference with and stoppage of the "interstate journey" of certain commodities. ${ }^{13}$ Typical examples of this are the Aeoli$a n^{x_{4}}$ and the Live Chicken ${ }^{15}$ cases. An analogous case is Anderson v. Shipowners' Association $n^{26}$ where the Court condemned conduct restraining "ships and those who operate them .... instrumentalities of interstate commerce." Indeed, I have frequently wondered if the Railway Labor Act was not an outgrowth of practical political necessity prompted by the fact that any coercive labor activity on the railroads necessarily restrained interstate commerce and the instrumentalities thereof directly-an occurrence against which the Court could not help applying the Sherman Act, no matter what the purpose of the labor dispute might be. Rather than permit this "impossible" situation, it is likely that Congress at an early date preferred to provide a substitute and retain some measure of political peace and harmony with the powerful railroad brotherhoods. But I am introducing this paragraph only for the record; hence $I$ shall revert to my main thesis.

Counsel for the plaintiff in the Apex case has little ground for complaining that the Third Circuit Court of Appeals reversed the very substantial judgment against the defendants. In my opinion he should have looked for and introduced evidence indicating that the Full Fashioned Hosiery Workers were out to unionize the entire industry, not only to achieve greater bargaining power but also to subserve organized labor's

${ }^{23}$ As to the Supreme Court's lack of enthusiasm about relying upon this type of restraint on interstate commerce, see its language in Levering \& Garrigues v. Morrin, 289 U.S. 103, Io7 (1933); note rg infra.

${ }^{14}$ Aeolian Co. v. Fischer, 40 F. (2d) I89 (C.C.A. 2 d r930).

Is Local 167, Int'l Brotherhood of Teamsters v. United States, 29r U.S. 293 (I934).

${ }^{26}$ Anderson v. Shipowners Ass'n of the Pacific Coast, 272 U.S. 359 (Ig26). 
main economic objective-the elimination of competition from nonunion made hosiery in national markets. I feel sure that such a motive was present and, although $I$ do not know that counsel could have obtained proof of it, I feel reasonably certain that he might have put something in the record on this point.

But now another consideration obtrudes itself into the discussion. The Supreme Court's position which I have been discussing was evolved in the nineteen-twenties, before the political and social changes of the succeeding decade had occurred. What difference does the Wagner Act make in the Court's position toward the coercive activities of organized labor? Under this new statute the unions may now bargain for and achieve the single or universal closed shop as a matter of right. If it can be shown that they do this partly in order to eliminate the competition of nonunion made goods from national markets, will their bargaining efforts and resulting collective agreements, if any, be illegal restraints under the Sherman Act? Obviously they will not be. Such a result would be so at variance with the clear policies of the Wagner Act that a court so deciding would appear ludicrous. Besides, it would be too easy for the Supreme Court to say that restraints of this kind so effected were "merely incidental" to the main objective sought for under the Wagner Act-the perfection of collective bargaining power.

But does this mean that the Wagner Act has done away with the sanctions of the Sherman Act against coercive self help organizational activities on the part of unions, such as occurred in the Apex case? The answer is plainly, most certainly not. Nothing in the Wagner Act was intended to encourage or to permit toleration of continued violent coercive activities. In fact, the statute was obviously designed to do away with coercive union activities altogether, although in Section $\mathrm{x} 3^{\text {I7 }}$ it left a loophole for self help bargaining pressure against recalcitrant employers. And many believe that since the Wagner Act or any other statute cannot completely obviate the necessity for union labor's occasional recourse to self help methods in collective bargaining, we should not, in a world so riddled with opposing interests, entertain this ideal commonly imputed to these new labor relations laws. But even these people would no doubt admit that the Sherman Act still remains as a sanction to control union coercive organizational activities which restrain interstate commerce. And if this is so, I should suppose that the position taken by the Supreme Court in the nineteentwenties is still current.

17 This section reads: "Nothing in this Act shall be construed so as to interfere with or impede or diminish in any way the right to strike." 
This position is, in brief, that labor unions may not coerce employers to accede to union demands by striking at their interstate trade or in order to do away with their interstate sales and shipments of nonunion made goods. As I intimated above, however, closed shop agreements secured by collective bargaining which is lawful under the Wagner Act may have the effect of keeping nonunion made goods from interstate commerce. Indeed, the policy of the act contemplates the complete unionization of industries supplying national markets and, hence, the complete elimination of the production of nonunion made goods. And I think it is now idle to suppose, merely because labor unions deliberately intend to bring this situation about by lawful collective bargaining, that such a result is illegal under the Sherman Act. But I think that the Sherman Act was designed to prevent the concentration of too much power in one centrally controlled business group or combination. Its policies, no doubt, rest somewhat on the common experience that exclusive power of a group over certain social activities creates an irresistible temptation to abuse the power.

Certainly trade unionism is a business enterprise designed purely and simply to advance the economic interests of its adherents. Why the union leaders should expect to be immune from the regulatory controls of the Sherman Act in their business dealings with industry is beyond my understanding. When they claim such activities to lie beyond these controls, I suppose that they are quite humanly trying to get away with all they can for themselves and their constituents. But surely they must not expect disinterested citizens, even those who enter the lists on the union side in the struggle for advancement of union organization and the principle of collective bargaining, to support their claims which are so patently inimical to the policies deemed wise for the control of monopolistic practices of business in general. For if union labor is to have the power which Congress in the Wagner Act intended it to acquire, then it must study to use this power in the business world as responsibly as any other big business must.

In United States 0. Brims ${ }^{18}$ it appeared that the building contractors, woodwork shops and the carpenters' union in the Chicago area entered into a three party contract whereby the contractors agreed to employ only union carpenters and to use only union made wood trim in their building operations, the woodwork mills agreed to employ only union carpenters, and the carpenters' union agreed to work only on union made wood trim in construction of buildings. The result, one which appears to have been intended, was the complete stoppage of shipments of wood trim

${ }^{8} 272$ U.S. 549 (I926). 
into Chicago from the nonunion mills of lower Illinois, Wisconsin and Indiana. The government sought and secured the dissolution of this agreement and the conspiracy carried on thereunder as contrary to the policies of the Sherman Act. If this situation were to recur tomorrow, there is absolutely no reason to suppose that the intervening passage of the Wagner Act would in any way prevent a repetition of the Supreme Court's decision in the Brims case. The only difference at all which the Wagner Act has made would be to legalize organizational campaigns, carried on by the federated carpenters' unions in order to unionize the out of town and out of state nonunion woodworking mills, the products of which have been competing with the local union mills. Successful campaigns of this sort, even if specifically intended to eliminate nonunion competition from out of state mills, would be legitimate under the federal laws. But this would be so, in my opinion at least, only if such campaigns pursuant to such intention were conducted without coercive self help and subject to the provisions of the Wagner Act under which the employees in the out of state mills would in official representation proceedings have the last word in deciding whether or not to affiliate with the federated union. Naturally, it goes without saying that the Sherman Act should apply to direct action such as interfering with specific shipments of out of state nonunion made materials sent into the Chicago market. ${ }^{\text {I9 }}$

One occasionally hears that the Norris-La Guardia anti-injunction act has drastically modified, if not completely eliminated, the application of the Sherman Act to the activities of labor unions. But it seems fairly obvious that the Norris-La Guardia Act was designed merely to prevent the real danger to civil rights arising from the abuse of the injunctive remedy. Naturally its provisions apply as much to the injunctive remedy sought under the Sherman Act either privately or at the instance of the

I9 In the former report of the Apex case, when it was before the Third Circuit Court of Appeals on the request for an injunction, appears the following paragraph: "There was also in the factory on the day of this calamitous advent of Leader and his followers finished merchandise for the spring trade worth about $\$ 600,000$ ready to be sent out on order into the 'stream' of interstate commerce. The plaintiff earnestly pleaded with Leader to permit it to ship this merchandise to the purchasers, but he has refused to permit a single piece to be moved." Apex Hosiery Co. v. Leader, go F. (2d) I55 (C.C.A. 3d r937).

In the latest report (Apex Hosiery Co. v. Leader, C.C.H. Lab. Law Serv. I $r 8482$ (C.C.A. $3^{\text {d }}$ I939)) the court similarly adverts to the refusal of Leader and his group to allow shipment of the stock on hand. Yet nothing was further said about this item in the court's opinion as constituting an illegal restraint on commerce, and no mention at all of this item appears in the lengthy charge to the jury by the district court. See C.C.H. Lab. Law Serv. If I8336 (D.C. Pa. I939). The inference, I suppose, is that the court either did not regard this question of shipment of goods as a restraint on commerce, or, if it did, chose not to regard it as a direct restraint or, perhaps, felt that it had not been properly called to the attention of the jury. 
Attorney General against the coercive activities of labor unions..$^{20}$ But I think it is a mistake to assume that a law which makes a particular activity non-enjoinable therefore, by implication, also renders it generally lawful for all purposes when it had previously been considered illegal. ${ }^{2 \mathrm{I}} \mathrm{I}$ am, of course, aware of the fact that aside from activities contrary to the provisions of specific statutes or involving violence, the practical effect of anti-injunction laws, particularly with respect to picketing, has been generally to legalize the coercive economic devices used by organized labor. This result was, perhaps, inevitable where the injunction was the only practicable remedy against the conduct in question.

But it is hard to see how the criminal and the civil action-for-tripledamages sanctions of the Sherman Act have been affected. The ordinary process observed in criminal and tort cases alone furnishes the guaranty of a fair hearing formerly absent in suits for injunctions against labor unions. Obviously there is no reason for concluding that these additional sanctions of the Sherman Act are no longer available as against the coercive activities of labor unions. Furthermore, it seems equally apparent that even the injunctive remedy, either at the instance of the Attorney General or of private litigants, still remains available as a device, under the Sherman Act to control the bargaining and other business activities of labor unions. For the Norris-La Guardia Act applies only in cases of "labor disputes"; and by no stretch of the imagination could ordinary trade agreements or the sort of arrangement under fire in the Brims case be regarded as labor disputes. For another instance, it seems clear to me that the labor union tie-up in the current Borden ${ }^{22}$ case is equally subject to injunctive prohibition in spite of the Norris-La Guardia Act.

Before I close this discussion, I should like to comment on at least one statement of the Third Circuit Court of Appeals, as presently constituted, made in the most recent chapter of the $A$ pex case. This was part of its comment on the effect of an alleged expanded notion of "interstate commerce" in the Wagner Act and in decisions under it. Apparently counsel for the plaintiff had urged the court to recognize as a "restraint" of interstate commerce such conduct as it would concede to "affect" interstate commerce in litigation arising under the Wagner Act. But the court re-

${ }^{20}$ It is noteworthy, however, that the Third Circuit Court of Appeals as formerly constituted apparently felt otherwise in the first Apex case. $90 \mathrm{~F}$. (2d) I55 (C.C.A. $3 \mathrm{~d}$ I937).

${ }^{2 x}$ This is acknowledged by the writer of the lengthy comment entitled Labor and the Sherman Act, 49 Yale L.J. $5^{18}$ (I940). On page 529 he concludes his remarks on this matter by saying: "The Norris-La Guardia Act deals only with the procedure of the federal courts, not with substantive law."

22 United States v. Borden, 60 S. Ct. r82 (I939). 
fused to do so; and it would be very difficult, indeed, to take issue with its position in this respect. We are, of course, not to rely merely upon the distinction between the words "restrain" and "affect" as they appear in the Sherman and Wagner Acts, respectively. But we must recognize the difference between the purposes of the two acts. The former is to prevent certain kinds of restraints on interstate commerce as the Supreme Court has come to define such restraints; the latter is to remove even those restraints on interstate commerce which are caused by the self help coercive activities of labor unions but which the Supreme Court has repeatedly held could not be included within the established conception of illegal restraints under the Sherman Act. If I may be more explicit, in every case under the Sherman Act involving the coercive activities of labor unions the Supreme Court has frankly admitted that interstate commerce was restrained; but in several of them it has declared that the restraints in question were not illegal restraints under that statute. In the Court's opinion, it was apparently not the purpose of Congress in that law to condemn what the court termed these "indirect" or "incidental" restraints. But these are the very restraints which the Wagner Act was intended to obviate. The current notion that the Supreme Court has developed two different concepts of interstate commerce under these two statutes is, in my opinion, erroneous, for it seems amply clear that it still adheres to the same old "transportational" concept.

Whatever happens eventually in the $A$ pex case, it seems fairly certain that the place of the Sherman Act is still prominent as an expression of governmental policy concerning and as a device for the regulation of the activities of organized labor unions. It is only unfortunate that this statute is so vague that it is really little more than a blanket exhortation by Congress to those concerned to prevent the concentration in the hands of any group of too much power over national business and industry. Truly, it puts a premium on free enterprise to discover by practical ventures how much power any group may assume and retain. It certainly contains no guiding rules for labor leaders "on the make"; and they will probably have to learn what the limits are by the wasteful but democratic method of trial and error with the Supreme Court as the teacher. 